Available online on 15.04.2020 at http://jddtonline.info
Open Access to Pharmaceutical and Medical Research
unrestricted non-commercial use, provided the original work is properly cited

Open@ Access

Research Article

\title{
A Pilot Study Indicating Valuation of C-Reactive Protein for Disease Outcome in Sickle Hemoglobin Patients of Central India
}

\author{
Dey Sarkar Purnima ${ }^{1}$, Gupta Gajendra Kumar ${ }^{2, *}$ \\ ${ }^{1}$ Department of Biochemistry, M.G.M. Medical College, A.B. Road, Indore-452001, M.P., India \\ ${ }^{2}$ School of Biochemistry, Devi Ahilya Vishwavidyalaya, Takshashila Campus, Khandwa Road, Indore-452001, M.P., India
}

\begin{abstract}
Evidences support the fact that sickle cell disease (SCD) is associated with a chronic inflammatory state characterized by ha emolysis. C-reactive protein level (CRP) and white blood cell (WBC) count considered as biomarkers for inflammation. Also, elevation of serum total lactate dehydrogenase (LDH) levels are found to be associated with haemolysis, this makes LDH a nonspecific marker which has to be in terpreted in a context of other markers of disease. The present study aims to assess the role of CRP levels, WBC counts, RBC counts, haemoglobin (Hb) concentrations and LDH levels in sickle hemoglobin (HbS) patients. Blood samples of $10 \mathrm{HbS}$ patients (six females and four males) attending M.Y. Hospital, Indore during the period of Aug to Oct 2019 were screened for CRP, LDH and Hb levels and RBC and WBC counts using latex enhanced immune-turbidimetric assay, LDH optimize DGKC kinetic and differential automated hematology analyzer respectively. Data (mean \pm SEM) was analyzed using Graphpad Prism software using Tukey's multiple comparison post-hoc test. The mean Hb levels (7.73 $\pm 0.81 \mathrm{~g} / \mathrm{dl})$ and RBC counts $(3.21 \pm 0.53$ million $/ \mu \mathrm{l})$ were found to be significantly decreased $(\mathrm{p}<0.001$ and 0.01 respectively) and mean WBC co unts $(15214.28$ \pm 1893.40 per $\left.\mathrm{mm}^{3}\right)$, CRP levels $(85.73 \pm 23.23 \mathrm{mg} / \mathrm{l})$ and LDH levels (1334.00 \pm 418.49 U/l) were found to be significantly increased ( $<<$ $0.0001,0.01$ and 0.01 respectively) in $\mathrm{HbS}$ patients in comparison with their respective controls. The variations in serum LDH and CRP levels are accompanied by changes in hematological parameters in HbS patients. These parameters may be considered as indicator of the severity of the disease.
\end{abstract}

Keywords: C-reactive protein, LDH, Sickle cell disease

Article Info: Received 26 Jan 2020; Review Completed 24 March 2020; Accepted 29 March 2020; Available online 15 April 2020

Cite this article as:

Dey Sarkar P, Gupta GK, A Pilot Study Indicating Valuation of C-Reactive Protein for Disease Outcome in Sickle Hemoglobin Patients of Central India , Journal of Drug Delivery and Therapeutics. 2020; 10(2-s):35-38 http://dx.doi.org/10.22270/jddt.v10i2-s.4030

*Address for Correspondence:

Gajendra K. Gupta, Ph.D. Research Fellow, School of Biochemistry, Devi Ahilya Vishwavidyalaya, Takshashila Campus, Khandwa Ro ad, Indore452001, M.P., India

\section{INTRODUCTION}

Sickle cell disease (SCD) or sickle cell anemia (SCA) is a recessive genetic disorder resulting in red blood cells forming into a sickled shape.1-3 The disease affected millions of people throughout the world and is particularly common among those whose ancestry comes from sub-Saharan Africa, Spanish-speaking regions in the Western Hemisphere (i.e., South America, the Caribbean and Central America), Saudi Arabia, India and Mediterranean countries such as Turkey, Greece and Italy.4 SCD is the most commonly found monogenic disease and has been recognized by the World Health Organization (WHO) as major public health problem. ${ }^{5}$ causing morbidity and mortality with tremendous social and economic impact mainly due to the recurrent acute episodic clinical events called "crises" and hospitalization. ${ }^{6}$

Common and important morbidities associated with SCD are vaso-occulsive episode ${ }^{7,8}$ including haemolysis, inflammation, infections, ${ }^{9}$ acute chest syndrome, ${ }^{10}$ stroke, ${ }^{11}$ renal failure, 12 hip necrosis and early deaths. ${ }^{13}$ Although there have been some advance in the management of SCD, much remains to be learned about the mechanism underlying the wide phenotypic diversity of the disease. In resources poor countries, basic facilities for diagnosis and management are lacking, systematic screening is not common practice and diagnosis is made late. The analysis of $\beta$-globin gene haplotypes in India using PCR-RFLP revealed four haplotypes, Arab-Indian, Senegal, Benin and Bantu/CAB, whereas the Cameroon haplotype did not found in the study subjects. The Arab-Indian haplotype was found most common haplotype (78\%) along with atypical haplotypes (15\%). Senegal, Benin and Bantu haplotypes were found in $4 \%, 2 \%$ and $1 \%$ respectively of these sickle cell disease patients. ${ }^{14}$

Some biomarkers have important role in the identification, understanding pathophysiological processes and management of SCD. ${ }^{15}$ Vaso-occlusive crisis activate and damages the endothelial cells with activation of adhesion 
molecules that lead to inflammation, release of $\mathrm{C}$-reactive protein (CRP) and other inflammatory mediators and subsequent enhancement of ischemia. ${ }^{16}$ Production of CRP is a part of a nonspecific acute phase response to inflammation and tissue necrosis. ${ }^{17}$ Elevated levels of CRP, as a general biomarker of inflammation have been previously reported in sickle hemoglobin (HbS) patients.18,19 White blood cell (WBC) count is also be considered as a biomarker of inflammation. ${ }^{20}$ As the frequency of vaso-occlusive episodes was a marker of poorer survival in patients with sickle cell anemia, 21 the study of this biomarkers may help in prevention of vaso-occlusive crisis.

Lactate dehydrogenase (LDH) is present in all the body cells and is found in high concentration in muscle cells, kidneys, erythrocytes, leucocytes, lungs, lymph nodes, spleen and brain. The elevation of LDH was associated with hemolysis, pain crisis, pulmonary hypertension, kidney damage and endothelial activation with elevated soluble vascular adhesion molecules. ${ }^{22}$ This makes LDH a nonspecific marker which has to be interpreted in a context of other markers of disease. Serum LDH level is elevated above the reference range in hemolytic states and this has been demonstrated in studies done on SCD patients. These studies have demonstrated a correlation between the serum LDH level and other markers of hemolysis such as bilirubin. ${ }^{23}$ Also, red blood cell (RBC) count and haemoglobin ( $\mathrm{Hb}$ ) concentration alters in hemolysis. The identification of LDH may be considered as marker of hemolysis and might be an important tool for the early detection of the severity of the disease in $\mathrm{HbS}$ patients.

The prevalence of sickle cell carriers among different tribal groups of India varies from 1-40\%. In Jabalpur, Madhya Pradesh, newborn screening has just been initiated. In India, Madhya Pradesh state has the highest load with sickle cell disease and the prevalence of $\mathrm{HbS}$ varies from $10-33 \% .24$ Therefore, it was found worth to screen the Indore region of Madhya Pradesh for our study. The present study aims to assess the role of CRP levels, WBC counts, RBC counts, haemoglobin $(\mathrm{Hb})$ concentrations and LDH levels in sickle hemoglobin (HbS) patients.

\section{MATERIAL AND METHODS}

Study Area and Design

This pilot study was conducted in Maharaja Yashwant Rao Hospital, Indore, Madhya Pradesh, India. This is a case control study included a total of ten patients (six females and four males) all of them were diagnosed with sickle cell anemia with $\mathrm{Hb}$ Electrophoresis and hospitalized. Six healthy females and four healthy males were included in the control group. Patients use hydroxyurea or any treatment which affect the results and in cooperation patients were excluded from the study. This study was approved by the Ethical Committee of Mahatma Gandhi Memorial Medical College, Indore and written informed consent was obtained from each participant before sample collection.

\section{Sample Collection and Laboratory Analysis}

In this pilot study, blood samples of ten $\mathrm{HbS}$ patients attending M.Y. Hospital, Indore during the period of Aug to Oct 2019 were screened for CRP, LDH and Hb levels and RBC and WBC counts. A sample of $5 \mathrm{ml}$ of blood was collected from each participant, from which $3 \mathrm{ml}$ was dispensed into ethylene diamine tetra acetic acid (EDTA) containing tubes for determination of $\mathrm{Hb}$ concentration, WBC and RBC count and $2 \mathrm{ml}$ into plain tubes for determination of CRP and LDH concentration. The serum level of CRP was assayed using latex enhanced immune-turbidimetric assay using an automated clinical chemistry analyzer (Randox Laboratories Ltd., UK). LDH was measured using LDH optimize DGKC kinetic method kits (ERBA Diagnostic, Mannheim, Germany). Hb levels and RBC and WBC counts were determined using differential automated hematology analyzer (LH-750, Beckman Coulter, USA).

\section{Statistical Analysis}

Results were expressed as mean \pm S.E.M. The data were analyzed by one-way analysis of variance (ANOVA) tracked by Tukey's multiple comparison tests. Probability values less than 0.05 were considered statistically significant in all the cases

\section{RESULT}

The mean $\mathrm{Hb}$ levels $(7.73 \pm 0.81 \mathrm{~g} / \mathrm{dl})$ and RBC counts $(3.21$ \pm 0.53 million $/ \mu \mathrm{l})$ were found to be significantly decreased ( $\mathrm{p}<0.001$ and 0.01 respectively) and mean WBC counts $\left(15214.28 \pm 1893.40\right.$ per $\left.\mathrm{mm}^{3}\right)$, CRP levels $(85.73 \pm 23.23$ $\mathrm{mg} / \mathrm{l})$ and LDH levels $(1334.00 \pm 418.49 \mathrm{U} / \mathrm{l})$ were found to be significantly increased $(\mathrm{p}<0.0001,0.01$ and 0.01 respectively) in $\mathrm{HbS}$ patients in comparison with their respective controls (table 1 and figure 1 ).

Table 1: Comparison of some hematological parameters and serum LDH and CRP levels of sickle cell anemic patients with normal individuals

\begin{tabular}{|c|c|c|c|}
\hline \multirow[t]{2}{*}{ S.No. } & \multirow[t]{2}{*}{ Parameter } & \multicolumn{2}{|c|}{ Value (Mean \pm S.E.M.) } \\
\hline & & Patient Group & Control Group \\
\hline 1 & Hemoglobin concentration (g/dl) & $7.73 \pm 0.81$ & $15.98 \pm 1.06^{*}$ \\
\hline 2 & RBC count (million/ $\mu \mathrm{l}$ ) & $3.21 \pm 0.53$ & $5.07 \pm 0.69 \#$ \\
\hline 3 & WBC count (per $\mathrm{mm}^{3}$ ) & $15214.28 \pm 1893.40$ & $6586.88 \pm 545.17 \&$ \\
\hline 4 & CRP level (mg/l) & $85.73 \pm 23.23$ & $6.26 \pm 0.73^{\#}$ \\
\hline 5 & LDH level (U/I) & $1334.00 \pm 418.49$ & $428.95 \pm 51.64^{\#}$ \\
\hline
\end{tabular}

Results are expressed as Mean \pm S.E.M.; $n=10$ in each group. Data was analyzed by one-way ANOVA followed by Tukey's multiple comparison test. Significance: ${ }^{*} \mathrm{p}<0.001,{ }^{*} \mathrm{p}<0.01$ and ${ }^{\&} \mathrm{p}<0.0001$ when compared with respective control group. RBC: red blood cells; WBC: white blood cells; CRP: C-reactive protein; LDH: lactate dehydrogenase. 


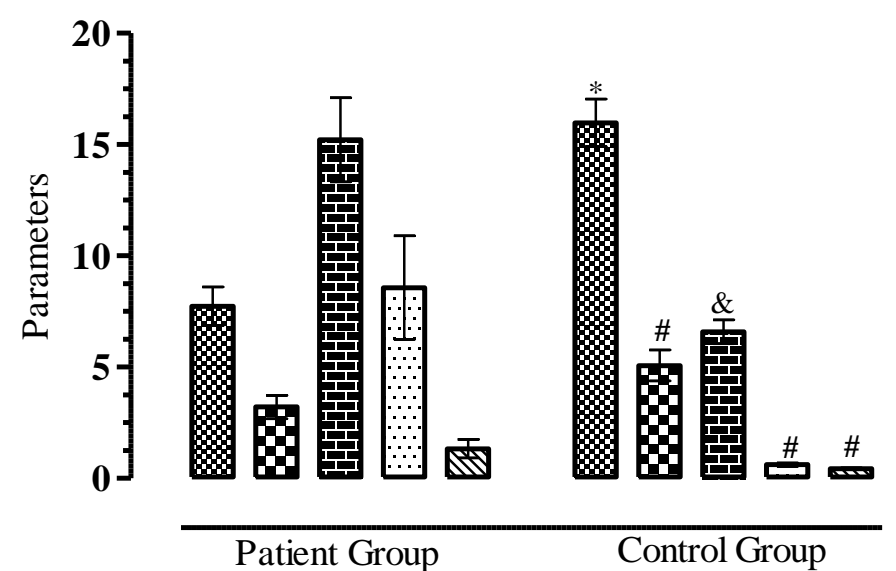

Figure 1: Comparison of some hematological parameters and serum LDH and CRP levels of sickle cell anemic patients with normal individuals

Results are expressed as Mean \pm S.E.M.; $\mathrm{n}=10$ in each group. Data was analyzed by one way ANOVA followed by Tukey's multiple comparison test. Significance: ${ }^{*} \mathrm{p}<0.001$, ${ }^{*} \mathrm{p}<0.01$ and ${ }^{\mathrm{p}} \mathrm{p}<0.0001$ when compared with respective control group. Hb: hemoglobin; RBC: red blood cells; WBC: white blood cells; CRP: C-reactive protein; LDH: lactate dehydrogenase.

\section{DISCUSSION}

In this study the mean $\mathrm{Hb}$ levels and RBC counts were found to be significantly decreased and mean WBC counts and LDH levels were found to be significantly increased in $\mathrm{HbS}$ patients in comparison with their respective controls.

LDH is considered a marker of haemolysis and an indicator of risk of morbidity and mortality in $\mathrm{HbS}$ patients. ${ }^{25}$ Our study showed that the values of Hb concentration and RBC count of $\mathrm{HbS}$ patients are lower than those of control subjects. The low rate of $\mathrm{Hb}$ in sickle cell patients is due to chronic haemolysis. ${ }^{22}$ In this pilot study, the number of WBC of $\mathrm{HbS}$ patients was higher compared to non-SCD subjects and our finding agreed with previous study conducted by Krishnan et al. (2010). ${ }^{26}$ It has been shown that the leukocyte is an important factor that leads to the hyper viscosity and the phenomenon of endothelial adhesion. ${ }^{27}$

In this study, we found that CRP level was higher in $\mathrm{HbS}$ patients than in control group individuals and this result is in agreement with a study conducted by Okocha et al. (2014).28 Additionally, most of the $\mathrm{HbS}$ patients developed one of the complications specially the vaso-occlusive crisis which is the most frequent and if not diagnosed early they may develop organ damage and die in early age. So, the early prediction of vaso-occlusive crisis by the detection of the CRP level which might be beneficial in disease management.

\section{CONCLUSION}

The conducted study confirmed that variation in serum LDH and CRP levels are accompanied by changes in hematological parameters in $\mathrm{HbS}$ patients. These parameters may be considered as indicator of the severity of the disease and may have a clinical impact in the prevention and management of vaso-occlusive crisis in Indian $\mathrm{HbS}$ patients.

\section{REFERENCES}

1. Creary M, Williamson D, Kulkarni R, Sickle cell disease: Current activities, public health, implications and future direction, J Women: S Health, 2007; 16:575-582.

2. Scott AA, Scott KD, Cultural therapeutic awareness and sickle cell anemia, J Black Psycology, 1999; 3:316-335.

3. Long KA, Thomas SB, Grubs RE, Getting EA, Krishnamurti L, Attitudes and beliefs of African-Americans towards genetics, genetic testing and sickle cell disease education and awareness, J Genetic Counsel, 2011; 20:572-592.

4. Centre for Disease Control and Prevention. Sickle cell disease (SCD). 2014. Retrieved April 1, 2014, from http:/www.cdc.gov/ncbddd/sickle cell/facts.html

5. Serjeant GR, Serjeant BE. Sickle cell disease. $1^{\text {st }}$ ed. New York: Oxford University Press; 1992.

6. Lena M, Ndugwa CM, Ddungu H, Idro R, Foetal haemoglobin and disease severity in sickle cell anaemia patients in Kampala, Uganda, J Androl, 2012; 32:375-382.

7. Jain D, Lothe A, Colah R, Sickle cell Disease: Current challenges. J Hematol Thromboemol Dis, 2015; 3:6-10.

8. Fattoum S, Hemoglobinopathies in Tunisia. An updated reviewof the epidemiologic and molecular data, Tunis Med, 2006; 84:687-696.

9. Elshazly SA, Heiba NM, Abdelmageed WM, Plasma PTX3 levels in sickle cell disease patients, during vaso-occlusion and acute chest syndrome (data from Saudi population), Hematology, 2014; 19:52-59.

10. Adisa OA, Hu Y, Ghosh S, Aryee D, Osunkwo I, Ofori-Acquah SF, Association between plasma free haem and incidence of vasoocclusive episodes and acute chest syndrome in children with sickle cell disease, Br J Haematol, 2013; 162:702-705.

11. Ruffieux N, Njamnshi AK, Wonkam A, Hauert CA, Chanal J, Verdon $\mathrm{V}$ et al., Association between biological markers of sickle cell disease and cognitive functioning amongst Cameroonian children, Child Neuropsychol, 2013; 19:143-160.

12. Emokpae MA, Uadia PO, Gadzama AA, Correlation of oxidative stress and inflammatory markers with the severity of sickle cell nephropathy, Ann Afr Med, 2010; 9:141-146.

13. Van Beers EJ, Yang Y, Raghavachari N, Tian X, Allen DT, Nichols JS et al., Iron, inflammation and early death in adults with sickle cell disease, Circ Res, 2015; 116:298-306.

14. Nongbri S, Rudy L, Verma HK, Lakkakula Bhaskar V.K.S., Patra PK, Presence of atypical beta globin $(H B B)$ gene cluster haplotypes in sickle cell anemia patients of India, Rev Bras Hematol Hemoter, 2017; 39:180-182.

15. Rees DC, Gibson JS, Biomarkers in sickle cell disease, British J Haematol, 2011; 156:433-444.

16. De FL, Mura P, Schweiger V, Vencato E, Quaglia FM, Delmonte $\mathrm{L}$ et al., Fentanyl buccal tablet: A new breakthrough pain medication in early management of severe vaso-occlusive crisis in sickle cell disease, Pain Pract, 2015; 26:1-10.

17. Bandeira IC, Rocha LB, Barbosa MC, Elias DB, Querioz JA, Freitas MV et al., Chronic inflammatory state in sickle cell anemia patients is associated with $\operatorname{HBB}(*) S$ haplotype, Cytokine, 2014; 65:210-217.

18. Mohammed FA, Mahdi N, Sater MA, Al-Ola K, Almawi WY, The relation of $\mathrm{C}$-reactive protein to vasoocclusive crisis in 
children with sickle cell disease, Blood Cells Mol Dis, 2010; 45:293-296.

19. Schnog JB, Mac Gillavry MR, van Zanten AP, Meijers JC, Rojer RA, Duits AJ et al., Protein C and S and inflammation in sickle cell disease, Am J Hematol, 2004; 76:26-32.

20. Misialek JR, Bekwelem W, Chen LY, Loehr LR, Agarwal SK, Soliman EZ et al., Association of white blood cell count and differential with the incidence of atrial fibrillation: The atherosclerosis risk in communities (ARIC) study,PLoS One, 2015; 10:e0136219.

21. Platt OS, Thorington BD, Brambilla DJ et al., Pain in sickle cell disease. Rates and risk factors, New Eng J Med, 1991; 325:1116.

22. Taylor, JG, Nolan VG, Mendelsohn L, Kato GJ, Gladwin MT, Steinberg MH, Chronic hyper-hemolysis in sickle cell anemia: association of vascular complication and mortality with less frequent vasoocclusive pain, PLos One, 2008; 3:e2095.

23. Mikobi TM, Lukusa Tshilobo P, Aloni MN, Mvumbi Lelo G, Akilimali PZ, Muyembe-Tamfum JJ, et al., Correlation between the lactate dehydrogenase levels with laboratory variables in the clinical severity of sickle cell anemia in Congolese patients, PLoS One, 2015; 10;e0123568.

24. Jain D, Lothe A, Colah R, sickle cell disease: Current challenges. J Hematology Thromboemol Dis, 2015; 3:6.

25. Connes P, Lamarre Y, Waltz X, Ballas SK, Lemonne N, EtienneJulan $\mathrm{M}$ et al., Haemolysis and abnormal haemorheology in sickle cell anaemia, Br J Haematol, 2014; 24:1-6.

26. Krishnan S, Setty Y, Betal SG, Vijender V, Rao K, Dampier C et al., Increased levels of the inflammatory biomarker C-reactive protein at baseline are associated with childhood sickle cell vasocclusive crises, Br J Haematol, 2010; 148:797-804.

27. Kasschau MR, Barabino GA, Bridges KR, Golan DE, Adhesion of sickle neutrophils and erythrocytes to fibronectin, Blood, 1996; 87:771-780.

28. Okocha C, Manafa P, Ozomba J, Ulasi T, Chukwuma G, Aneke J, $\mathrm{C}$-reactive protein and disease outcome in Nigerian sickle cell disease patients, Ann Med Health Sci Res, 2014; 4:701-705. 